\title{
Synthesis and Diels-Alder Reactivity of 4-Fluoro-4-Methyl-4H-Pyrazoles
}

\author{
Nile S. Abularrage $\mathbb{D}^{D}$, Brian J. Levandowski ${ }^{\mathbb{D}}$ and Ronald T. Raines * \\ Department of Chemistry, Massachusetts Institute of Technology, Cambridge, MA 02139-4307, USA; \\ nile@mit.edu (N.S.A.); levandbj@mit.edu (B.J.L.) \\ * Correspondence: rtraines@mit.edu; Tel.: +1-617-253-1470
}

Received: 23 April 2020; Accepted: 24 May 2020; Published: 31 May 2020

check for updates

\begin{abstract}
H-Pyrazoles are emerging scaffolds for "click" chemistry. Late-stage fluorination with Selectfluor ${ }^{\circledR}$ is found to provide a reliable route to 4-fluoro-4-methyl-4H-pyrazoles. 4-Fluoro-4-methyl-3,5-diphenyl-4H-pyrazole (MFP) manifested 7-fold lower Diels-Alder reactivity than did 4,4-difluoro-3,5-diphenyl-4H-pyrazole (DFP), but higher stability in the presence of biological nucleophiles. Calculations indicate that a large decrease in the hyperconjugative antiaromaticity in MFP relative to DFP does not lead to a large loss in Diels-Alder reactivity because the ground-state structure of MFP avoids hyperconjugative antiaromaticity by distorting into an envelope-like conformation like that in the Diels-Alder transition state. This predistortion enhances the reactivity of MFP and offsets the decrease in reactivity from the diminished hyperconjugative antiaromaticity.
\end{abstract}

Keywords: antiaromaticity; click chemistry; cycloaddition; $4 H$-pyrazole; hyperconjugation

\section{Introduction}

Discovered in 1928 [1], the Diels-Alder reaction has become a mainstay of synthetic organic chemistry and allied fields [2-6]. Diels-Alder reactions of 4H-pyrazoles, in particular, have been explored by the groups of Adam and Hünig [7-10]. 4H-Pyrazoles with alkyl or chloro substituents at the saturated center require acid catalysis to proceed, whereas $4 H$-pyrazoles bearing electron-withdrawing fluoro substituents react rapidly as Diels-Alder dienes in the absence of an acid [11]. Density functional theory (DFT) calculations show that the uncatalyzed Diels-Alder reaction of 4,4-difluoro-3,5-diphenyl-4H-pyrazole (DFP) proceeds $~ 500,000$ times faster than does the reaction of 4,4-dimethyl-3,5-diphenyl-4H-pyrazole with the strained alkyne, endo-bicyclo[6.1.0]non-4-yn-9-ylmethanol $(\mathrm{BCN})$. This increase in reactivity is the result of the hyperconjugative antiaromaticity [12-15] and the lowering of the lowest unoccupied molecular orbital (LUMO) energy induced by the electron-withdrawing fluoro substituents.

Our group is interested in developing the $4 \mathrm{H}$-pyrazole scaffold as a reagent for "click" chemistry [16]. Recently, we showed that the 4,4-difluoro- $4 H$-pyrazole scaffold is more reactive than the tetrazine scaffold towards BCN. The rapid Diels-Alder reactivity came, however, with a reduction in the stability of the diene scaffold toward biological nucleophiles, which limits the utility of 4,4-difluoro- $4 H$-pyrazoles in physiological environments. In an effort to maintain rapid Diels-Alder reactivity without sacrificing stability, we have turned our attention to the facially asymmetric 4-fluoro-4-methyl-4H-pyrazole scaffold.

The general method for synthesizing $4 H$-pyrazoles is the condensation reaction of 1,3-diketones with hydrazine, as shown in Scheme 1 [17]. The reaction of hydrazine with diketones containing electron-withdrawing substituents at the 1- and 3-positions predominately leads to the corresponding 5-hydroxy-2-pyrazoline instead of the corresponding $4 H$-pyrazole because the dehydration step 
becomes difficult. For example, the reaction of 4-nitrobenzoylacetone with hydrazine results in the exclusive formation of the 5-hydroxy-2-pyrazoline [18].

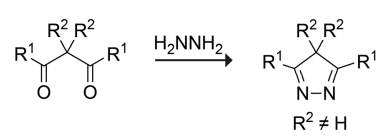

Scheme 1. Synthesis of $4 H$-pyrazoles by condensation of 1,3-diketones with hydrazine.

The previously reported synthetic route to DFP $(R=P h)$ and its analogs is shown in Scheme $2[19,20]$. Synthesis is accomplished by reacting a $1 H$-pyrazole with two equivalents of 1-chloromethyl-4-fluoro-1,4-diazoniabicyclo[2.2.2] octane bis(tetrafluoroborate) (Selectfluor ${ }^{\circledR}$ ), which is a highly reactive electrophilic fluorinating agent [21-23]. This route suffers from a limited substrate scope when electron-withdrawing substituents are present at the 3- and 5-positions of the pyrazole ring. The electron-withdrawing substituents lower the nucleophilicity of the fluorinated pyrazole, which makes the addition of a second electrophilic fluorine difficult. To circumvent these shortcomings and develop a generalized method for synthesizing electron-deficient $4 H$-pyrazoles, we sought another route. We also explored the Diels-Alder reactivity of an ensuing $4 H$-pyrazole.

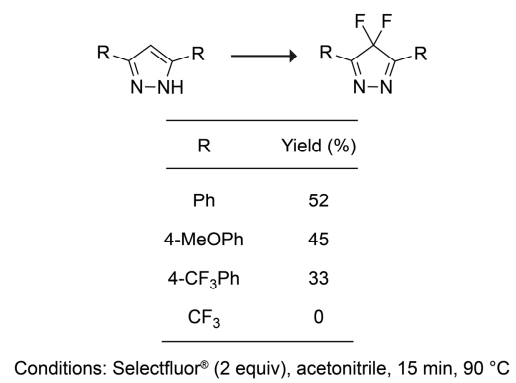

Scheme 2. Synthesis of various substituted 4,4-difluoro-4H-pyrazoles. Data/Adapted from [19].

\section{Results and Discussion}

To begin, we examined the physical properties of the 4,4-difluoro-4H-pyrazole and 4-fluoro-4-methyl-4H-pyrazole scaffolds with density functional theory calculations at the M06-2X/6-311++G(d,p)//M06-2X/6-31G(d) level of theory [24]. The rapid Diels-Alder reactivity of the DFP scaffold is attributed to its hyperconjugative antiaromaticity and low-lying LUMO energy [11]. The isodesmic equations in Scheme 3 report on the destabilization that results from hyperconjugative antiaromatic electron delocalization [11-15,25,26]. The reaction enthalpies of the isodesmic equations suggest that hyperconjugative antiaromaticity destabilizes the 4,4-difluoro- $4 H$-pyrazole and 4-fluoro-4-methyl-4H-pyrazole scaffolds by 5.8 and $1.4 \mathrm{kcal} / \mathrm{mol}$, respectively. The calculated LUMO energies are -2.0 and $-1.3 \mathrm{eV}$ for the 4,4-difluoro-4H-pyrazole and 4-fluoro-4-methyl-4H-pyrazole scaffolds, respectively.

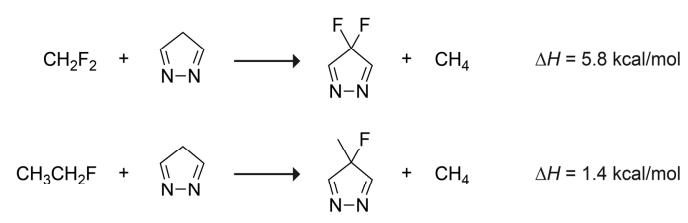

Scheme 3. Reaction enthalpies of isodesmic equations to estimate the hyperconjugative antiaromaticity in the 4,4-difluoro-4H-pyrazole (top) and 4-fluoro-4-methyl-4H-pyrazole (bottom) scaffolds.

Next, we computationally explored the Diels-Alder reactivity of the electron-deficient 4H-pyrazole scaffolds. The computed transition-state structures and Gibbs free energies of activation and reaction 
for the Diels-Alder reactions of the 4-fluoro-4-methyl-4H-pyrazole and 4,4-difluoro- $4 \mathrm{H}$-pyrazole scaffolds towards BCN are shown in Figure 1. Despite the significantly lower LUMO energy and decreased hyperconjugative antiaromaticity of the 4-fluoro-4-methyl-4H-pyrazole scaffold relative to the 4,4-difluoro- $4 H$-pyrazole scaffold, they have similar Diels-Alder reactivities towards BCN with Gibbs free energies of activation of 16.0 and $15.2 \mathrm{kcal} / \mathrm{mol}$, respectively. The 4,4-difluoro- $4 H$-pyrazole scaffold is planar, whereas the 4-fluoro-4-methyl- $4 H$-pyrazole scaffold is puckered by $3^{\circ}$ into an envelope-like geometry that minimizes the destabilizing effects of hyperconjugative antiaromaticity [15]. The puckering causes the diene to adopt a conformation closer to that of the syn Diels-Alder transition state and increases reactivity by reducing the conformational distortion needed to access the transition-state geometry.
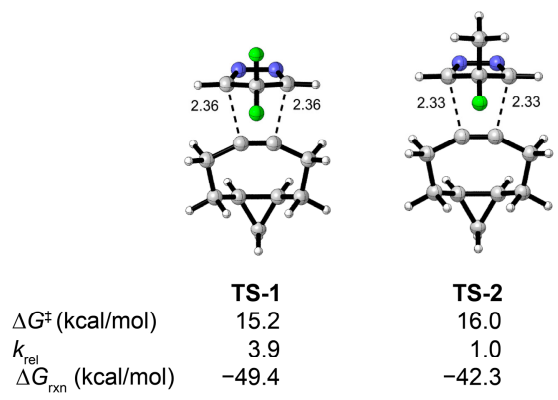

Figure 1. Transition-state geometries and calculated Gibbs free energies of activation $\left(\Delta G^{\ddagger}\right)$ and reaction $\left(\Delta G_{\text {rxn }}\right)$ computed at the M06-2X/6-311++G(d,p)//M06-2X/6-31G(d) level of theory for the Diels-Alder reactions of 4,4-difluoro-4H-pyrazole (TS-1) and 4-fluoro-4-methyl-4H-pyrazole (TS-2) scaffolds toward endo-bicyclo[6.1.0]non-4-yn-9-ylmethanol (BCN) lacking the 9-hydroxymethyl group. The lengths ( $\AA$ ) of forming bonds are shown. Values of $k_{\text {rel }}$ were calculated at $298 \mathrm{~K}$ with the Arrhenius equation.

To test its reactivity experimentally, we set out to synthesize a representative 4-fluoro-4-methyl-4H-pyrazole. As the reactivity of 4,4-difluoro-3,5-diphenyl-4H-pyrazole (DFP) is known [11], we chose 4-fluoro-4-methyl-3,5-diphenyl-4H-pyrazole (MFP) as a target. Initially, we synthesized MFP via the condensation of 2-fluoro-2-methyl-1,3-diphenylpropane-1,3-dione (3) with hydrazine (Scheme 4, Method A). The final step in Method A suffered from a low overall yield of $34 \%$ because the second dehydration step is difficult when electron-withdrawing substituents, such as a fluoro group, are present [18]. In our hands, this reaction was also inconsistent and ineffective when attempted on a larger scale, leading us to seek a new route.

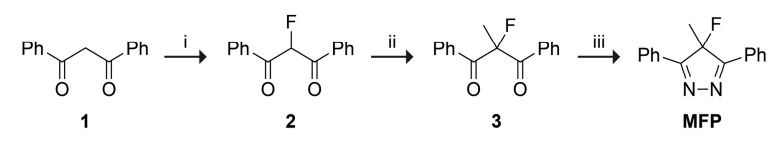

Scheme 4. Method A for the preparation of 4-fluoro-4-methyl-3,5-diphenyl-4H-pyrazole (MFP). Conditions and yields: i. Selectfluor ${ }^{\circledR}$, acetonitrile, RT, $2.5 \mathrm{~h}, 96 \%$; ii. $\mathrm{MeI}, \mathrm{K}_{2} \mathrm{CO}_{3}, \mathrm{DMF}, 60{ }^{\circ} \mathrm{C}, 3 \mathrm{~h}$, $88 \%$; iii. $\mathrm{H}_{2} \mathrm{NNH}_{2}$, DCM, reflux, 18 h, $34 \%$.

Inspired by the successful preparation of 4-chloro-4-methyl-4H-pyrazoles by the late-stage chlorination of $1 \mathrm{H}$-pyrazoles with tert-butyl hypochlorite [7], we turned to late-stage fluorination of a $1 H$-pyrazole. Although this strategy is similar to that for synthesizing DFP $[11,19,20]$, the difficult step in the synthesis of DFP is the low-yielding nucleophilic addition of the second fluorine. That would not be a concern in the preparation of MFP. Fluorination of $1 H$-pyrazoles to yield 4-fluoro- $1 \mathrm{H}$-pyrazoles has been accomplished previously with Selectfluor ${ }^{\circledR}[27]$, but this method has not been used to prepare $4 H$-pyrazoles. Fluorination of 4-methyl-3,5-diphenyl- $1 H$-pyrazole (5) with Selectfluor ${ }^{\circledR}$ resulted in a 77\% yield of MFP (Scheme 5, Method B). The overall yields were $29 \%$ for Method A and $49 \%$ for Method B. Moreover, Method B was more consistent in our hands than Method A and proceeded well 
at larger scales. We anticipated that this new preparatory method will also be useful for accessing derivatives of MFP.

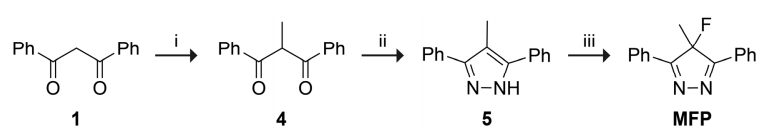

Scheme 5. Method B for the preparation of 4-fluoro-4-methyl-3,5-diphenyl-4H-pyrazole (MFP).

Conditions and yields: i. MeI, $\mathrm{K}_{2} \mathrm{CO}_{3}, \mathrm{DMF}, 60^{\circ} \mathrm{C}, 30 \mathrm{~min}, 72 \%$; ii. $\mathrm{H}_{2} \mathrm{NNH}_{2}, \mathrm{DCM}, \mathrm{RT}, 18 \mathrm{~h}, 88 \%$; iii.

Selectfluor ${ }^{\circledR}$, acetonitrile, reflux, $1 \mathrm{~h}, 77 \%$.

With a reliable strategy for the preparation of MFP in hand, we turned our attention to its experimental Diels-Alder reactivity and physiological stability. We measured the rate constant for the Diels-Alder reaction of MFP with BCN in 9:1 methanol/water at $\sim 20^{\circ} \mathrm{C}$ under pseudo-first-order conditions. A plot of the observed rate constants with respect to the $\mathrm{BCN}$ concentration is shown in Figure 2. From these data, we calculated that the Diels-Alder reaction proceeded with a second-order rate constant of $k=0.76 \mathrm{M}^{-1} \mathrm{~s}^{-1}$, which is 7-fold slower than that of DFP with $\mathrm{BCN}\left(k=5.2 \mathrm{M}^{-1} \mathrm{~s}^{-1}\right)$ [11].
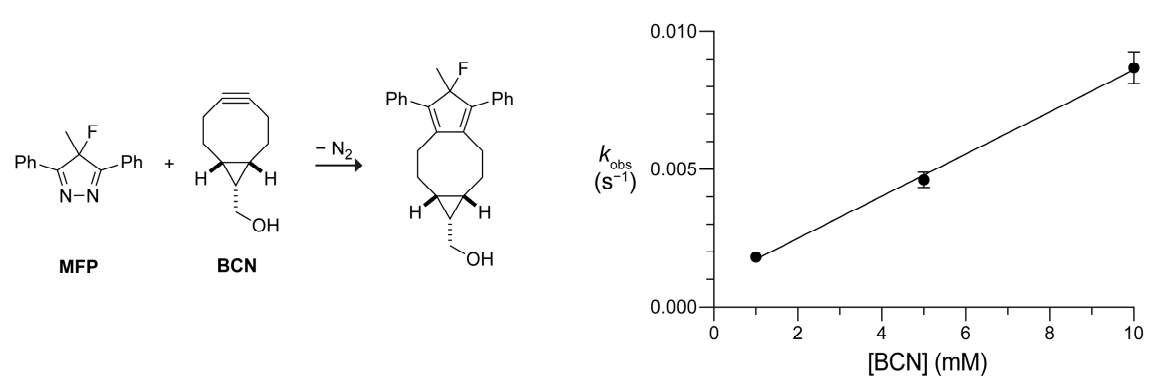

Figure 2. Reaction of endo-bicyclo[6.1.0]non-4-yn-9-ylmethanol (BCN) (1, 5, or $10 \mathrm{mM})$ with 4-fluoro-4-methyl-3,5-diphenyl-4H-pyrazole (MFP) (0.1 mM) in 9:1 methanol/water. Values of $k_{\mathrm{obs}}$ are the mean \pm SD for reactions performed in triplicate. The second-order rate constant as calculated from a linear fit of the data was $k=0.76 \mathrm{M}^{-1} \mathrm{~s}^{-1}\left(R^{2}=0.99\right)$.

To assess the physiological stability of MFP and DFP, we incubated both in phosphate-buffered saline (PBS) containing fetal bovine serum (FBS; $10 \% v / v$ ) at $37^{\circ} \mathrm{C}$. After $8 \mathrm{~h}, 42 \%$ of the DFP and $64 \%$ of the MFP remained intact (Figure 3). Thus, replacement of one fluoro group with a methyl group increased the stability of the $4 H$-pyrazole scaffold in serum by $52 \%$. We also examined the stability of MFP and DFP at $37^{\circ} \mathrm{C}$ in PBS containing reduced glutathione $(1.0 \mathrm{mM})$ and oxidized glutathione $(0.2 \mathrm{mM})$, which is a biomimetic redox buffer containing sulfhydryl, amino, and carboxyl groups [28]. We found that neither MFP nor DFP remained intact after an $8 \mathrm{~h}$ incubation (Figure 3). The physiological stability studies show that MFP is more stable than DFP, however, both MFP and DFP are compromised in the presence of biological nucleophiles. 


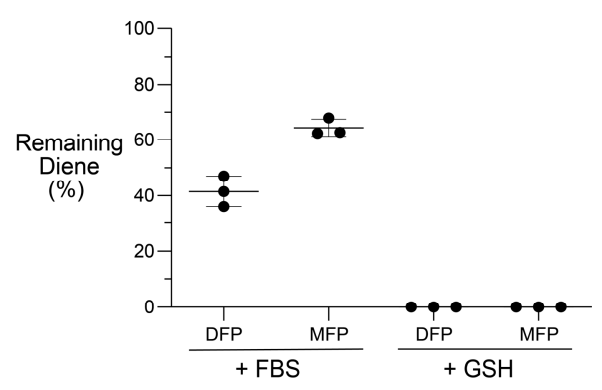

Figure 3. Stability of 44,-difluoro-4-methyl-3,5-diphenyl-4H-pyrazole (DFP) and 4-fluoro-4-methyl3,5-diphenyl-4H-pyrazole (MFP) in the presence of fetal bovine serum (FBS) or glutathione (GSH). Percent remaining was determined after an $8 \mathrm{~h}$ incubation at $37^{\circ} \mathrm{C}$ as measured by UV-vis spectroscopy. In the presence of FBS, $(42 \pm 5) \%$ and $(64 \pm 3) \%$ of the DFP and MFP remained intact, respectively. No diene was detectable in the presence of GSH. Data for the stability of DFP in the presence of FBS are from [11].

\section{Materials and Methods}

\subsection{Materials}

\subsubsection{General}

All chemicals were from commercial sources and were used without further purification. NMR spectra were acquired with a Avance Neo 400 spectrometer or Avance Neo 500 spectrometer from Bruker (Billerica, MA, USA) and are shown in the Supplementary Materials. Mass spectra were acquired by using positive ionization with an AccuTOF-DART 4G instrument from JEOL (Tokyo, Japan). UV-vis experiments were carried out with an Cary $60 \mathrm{UV}$-vis spectrometer from Agilent Technologies (Santa Clara, CA, USA) with measurements every $0.1 \mathrm{~s}$ for kinetic experiments and absorbance scans for stability studies.

Column chromatography was performed with a Isolera automated purification system from Biotage (Uppsala, Sweden) using prepacked SNAP KP silica gel columns.

The phrase "concentrated under reduced pressure" refers to the removal of solvents and other volatile materials using a rotary evaporator at water aspirator pressure $(<20$ Torr) while maintaining the water-bath temperature of $40^{\circ} \mathrm{C}$. Residual solvent was removed from samples by the vacuum $(<0.1$ Torr $)$ achieved by a mechanical belt-drive oil pump.

All procedures were performed in air at ambient temperature $\left(\sim 22^{\circ} \mathrm{C}\right)$ and pressure $(1.0 \mathrm{~atm})$ unless indicated otherwise.

\subsubsection{Synthesis of 2-Fluoro-1,3-diphenylpropane-1,3-dione (2)}

1,3-Diphenylpropane-1,3-dione (1) (1.5 g, $6.6 \mathrm{mmol})$ and 1-chloromethyl-4-fluoro-1,4diazoniabicyclo[2.2.2] octane bis(tetrafluoroborate) $(2.34 \mathrm{~g}, 6.6 \mathrm{mmol})$ were dissolved in $50 \mathrm{~mL}$ of acetonitrile and stirred for $2.5 \mathrm{~h}$. The reaction mixture was concentrated under reduced pressure, and the residue was taken up with DCM. The DCM was washed (3×) with water, dried over $\mathrm{Na}_{2} \mathrm{SO}_{4}(\mathrm{~s})$, filtered, and concentrated under reduced pressure. The product was purified by chromatography on silica gel, eluting $0-10 \% v / v$ ethyl acetate in hexanes to give $1.5356 \mathrm{~g}$ of $\mathbf{2}(96 \%)$ as a light orange solid. ${ }^{1} \mathrm{H}$ NMR $\left(400 \mathrm{MHz} \mathrm{CDCl}_{3}, \delta\right): 8.12(\mathrm{~d}, J=7.7 \mathrm{~Hz}, 4 \mathrm{H}), 7.71-7.56(\mathrm{~m}, 2 \mathrm{H}), 7.51(\mathrm{t}, J=7.6 \mathrm{~Hz}, 4 \mathrm{H}), 6.56$ $(\mathrm{d}, J=49.2 \mathrm{~Hz}, 1 \mathrm{H}) .{ }^{13} \mathrm{C}$ NMR $\left(101 \mathrm{MHz}, \mathrm{CDCl}_{3}, \delta\right): 191.29,134.54,129.86,129.83,128.81,97.61,95.64$. ${ }^{19}$ F NMR $\left(376 \mathrm{MHz}, \mathrm{CDCl}_{3}, \delta\right):-186.82(\mathrm{~d}, J=49.3 \mathrm{~Hz})$. HRMS $m / z$ calcd for $\mathrm{C}_{15} \mathrm{H}_{12} \mathrm{FO}_{2}[\mathrm{M}+\mathrm{H}]^{+}$, 243.08213; found, 243.08385. 


\subsubsection{Synthesis of 2-Fluoro-2-methyl-1,3-diphenylpropane-1,3-dione (3)}

Compound 2 (500 mg, $2.06 \mathrm{mmol})$ and $\mathrm{K}_{2} \mathrm{CO}_{3}(427 \mathrm{mg}, 2.09 \mathrm{mmol})$ were dissolved in $5 \mathrm{~mL}$ of $\mathrm{DMF}$, and $\mathrm{MeI}(0.282 \mathrm{~mL}, 643 \mathrm{mg}, 4.53 \mathrm{mmol})$ was added to the resulting solution. The reaction mixture was heated to $60^{\circ} \mathrm{C}$ and stirred for $3 \mathrm{~h}$. The reaction was quenched by the addition of $50 \mathrm{~mL}$ of $\mathrm{H}_{2} \mathrm{O}$, and the reaction mixture was extracted $(3 \times)$ with ethyl acetate. The combined organic layers were dried over $\mathrm{Na}_{2} \mathrm{SO}_{4}(\mathrm{~s})$, filtered, and concentrated under reduced pressure. The product was purified by chromatography on silica gel, eluting with $0-20 \% v / v$ ethyl acetate in hexanes to give $462 \mathrm{mg}$ of $3(88 \%)$ as a transparent gel. ${ }^{1} \mathrm{H}$ NMR $\left(500 \mathrm{MHz}, \mathrm{CDCl}_{3}, \delta\right): 8.04(\mathrm{dt}, J=8.5,1.5 \mathrm{~Hz}, 4 \mathrm{H}), 7.65-7.56(\mathrm{~m}, 2 \mathrm{H})$, $7.47(\mathrm{t}, J=7.8 \mathrm{~Hz}, 4 \mathrm{H}), 2.07(\mathrm{~d}, J=23.0 \mathrm{~Hz}, 3 \mathrm{H}) .{ }^{13} \mathrm{C}$ NMR $\left(126 \mathrm{MHz} \mathrm{CDCl}_{3}, \delta\right): 194.17,193.98,133.96$, 130.01, 129.97, 128.74, 22.10, 21.92. ${ }^{19}$ F NMR $\left(471 \mathrm{MHz}, \mathrm{CDCl}_{3}, \delta\right):-144.92(\mathrm{q}, J=23.0 \mathrm{~Hz})$. HRMS $\mathrm{m} / \mathrm{z}$ calcd for $\mathrm{C}_{16} \mathrm{H}_{14} \mathrm{FO}_{2}[\mathrm{M}+\mathrm{H}]^{+}$, 257.09778; found, 257.10300.

\subsubsection{Synthesis of 4-Fluoro-4-methyl-3,5-diphenyl-4H-pyrazole (MFP) Using Method A}

Compound 3 (50 mg, $0.206 \mathrm{mmol}$ ) was added to an oven-dried flask equipped with a reflux condenser. The flask was purged with $\mathrm{N}_{2}(\mathrm{~g})$. Hydrazine $(6.43 \mu \mathrm{L}, 6.62 \mathrm{mg}, 0.206 \mathrm{~mL})$ dissolved in $1 \mathrm{~mL}$ of dry DCM was added to the flask. The reaction mixture was heated at reflux with stirring for $18 \mathrm{~h}$ and then concentrated under reduced pressure. The product was purified by chromatography on silica gel, eluting with $0-20 \%$ v/v ethyl acetate in hexanes, to yield $17.5 \mathrm{mg}$ MFP $(34 \%)$ as a yellow solid. ${ }^{1} \mathbf{H}$ NMR $\left(400 \mathrm{MHz}, \mathrm{CDCl}_{3}, \delta\right): 8.26-8.00(\mathrm{~m}, 4 \mathrm{H}), 7.67-7.44(\mathrm{~m}, 6 \mathrm{H}), 1.90(\mathrm{~d}, J=22.8 \mathrm{~Hz}, 3 \mathrm{H}) .{ }^{13} \mathrm{C}$ NMR $\left(101 \mathrm{MHz}, \mathrm{CDCl}_{3}, \delta\right): 170.48,132.00,129.05,128.10,128.07,88.64,23.97 .{ }^{19} \mathrm{~F}$ NMR $\left(376 \mathrm{MHz}, \mathrm{CDCl}_{3}, \delta\right)$ : $-170.93(\mathrm{q}, J=22.7 \mathrm{~Hz})$. HRMS $m / z$ calcd for $\mathrm{C}_{16} \mathrm{H}_{14} \mathrm{FN}_{2}[\mathrm{M}+\mathrm{H}]^{+}$, 253.11410; found, 253.12166.

\subsubsection{Synthesis of 2-Methyl-1,3-diphenylpropane-1,3-dione (4)}

1,3-Diphenylpropane-1,3-dione (1) $(1.121 \mathrm{~g}, 5 \mathrm{mmol})$ and $\mathrm{K}_{2} \mathrm{CO}_{3}(1.037 \mathrm{~g}, 7.5 \mathrm{mmol})$ were dissolved in $10 \mathrm{~mL}$ DMF, and MeI $(0.781 \mathrm{~g}, 5.5 \mathrm{mmol}, 0.342 \mathrm{~mL})$ was added to the resulting solution. The reaction mixture was heated to $60^{\circ} \mathrm{C}$ and stirred for $30 \mathrm{~min}$. The reaction mixture was diluted with $50 \mathrm{~mL}$ of water and extracted with DCM. The organic layer was washed with water, dried over $\mathrm{Na}_{2} \mathrm{SO}_{4}(\mathrm{~s})$, filtered, and concentrated under reduced pressure. The product was purified by chromatography on silica gel, eluting with $0-10 \% v / v$ ethyl acetate in hexanes, then dried to give $0.8591 \mathrm{~g}$ of $\mathbf{2}(72 \%)$ as a light pink solid. ${ }^{1} \mathrm{H}$ NMR $\left(500 \mathrm{MHz}, \mathrm{CDCl}_{3}, \delta\right): 8.00-7.95(\mathrm{~m}, 4 \mathrm{H}), 7.61-7.57(\mathrm{~m}, 2 \mathrm{H}), 7.48(\mathrm{t}, J=7.8 \mathrm{~Hz}$, $4 \mathrm{H}), 5.29(\mathrm{q}, J=7.0 \mathrm{~Hz}, 1 \mathrm{H}), 1.63(\mathrm{~d}, J=7.0 \mathrm{~Hz}, 3 \mathrm{H}) .{ }^{13} \mathrm{C} \mathrm{NMR}\left(126 \mathrm{MHz}, \mathrm{CDCl}_{3}, \delta\right): 197.19,135.68$, 134.34, 133.50, 129.32, 128.91, 128.57, 51.10, 14.39. HRMS $m / z$ calcd for $\mathrm{C}_{16} \mathrm{H}_{15} \mathrm{O}_{2}[\mathrm{M}+\mathrm{H}]^{+}, 239.10720$; found, 239.10846 .

\subsubsection{Synthesis of 4-Methyl-3,5-diphenyl-1H-pyrazole (5)}

Compound 4 (200 mg, $0.84 \mathrm{mmol})$ was dissolved in $5 \mathrm{~mL}$ of DCM, and hydrazine hydrate (40 $\mu \mathrm{L}, 42 \mathrm{mg}, 0.84 \mathrm{mmol}$ ) was added to the resulting solution. The reaction mixture was stirred for $18 \mathrm{~h}$, which resulted in the solution becoming cloudy. The reaction mixture was then concentrated under reduced pressure and the product was purified by chromatography on silica gel, eluting with $20-50 \%$ $v / v$ ethyl acetate in hexanes to give $173 \mathrm{mg}$ of $5(88 \%)$ as a white solid. ${ }^{1} \mathbf{H}$ NMR $\left(400 \mathrm{MHz}\right.$, DMSO- $d_{6}$,

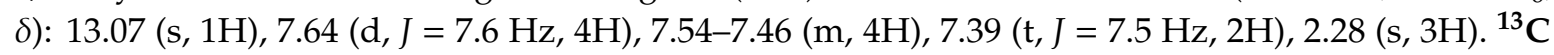
NMR $\left(101 \mathrm{MHz}\right.$, DMSO- $\left.d_{6}, \delta\right): 148.19,129.10,128.02,127.99,127.83,109.89,10.60$. HRMS $\mathrm{m} / z$ calcd for $\mathrm{C}_{16} \mathrm{H}_{15} \mathrm{~N}_{2}[\mathrm{M}+\mathrm{H}]^{+}$, 235.12352; found, 235.12784 .

\subsubsection{Synthesis of 4-Fluoro-4-methyl-3,5-diphenyl-4H-pyrazole (MFP) Using Method B}

Compound 5 (100 mg, $0.43 \mathrm{mmol}$ ) and 1-chloromethyl-4-fluoro-1,4-diazoniabicyclo[2.2.2]octane bis(tetrafluoroborate) $(151 \mathrm{mg}, 0.43 \mathrm{mmol})$ were added to an oven-dried flask, along with activated 3- $\AA$ molecular sieves. The flask was purged with $\mathrm{N}_{2}(\mathrm{~g})$, and $3 \mathrm{~mL}$ of dry acetonitrile was added. The reaction mixture was heated at $90{ }^{\circ} \mathrm{C}$ for $1 \mathrm{~h}$, diluted by the addition of $5 \mathrm{~mL}$ of ethyl acetate, 
filtered, and concentrated under reduced pressure. The product was purified by chromatography on silica gel, eluting with $0-10 \% v / v$ ethyl acetate in hexanes to give $84 \mathrm{mg}$ of MFP $(77 \%)$ as a light yellow solid. Characterization data matched those for MFP prepared according to Method A.

\subsection{UV-vis Kinetics}

Stock solutions of MFP $(200 \mu \mathrm{M})$ and $\mathrm{BCN}(20 \mathrm{mM}, 10 \mathrm{mM}$, and $2 \mathrm{mM})$ were prepared in 9:1 $\mathrm{MeOH} / \mathrm{H}_{2} \mathrm{O}$. A $0.5-\mathrm{mL}$ aliquot of the MFP stock solution was mixed with $0.5 \mathrm{~mL}$ of each BCN solution, and the absorbance at $335 \mathrm{~nm}$ was monitored until no MFP remained. Each reaction was carried out in triplicate. Values of $k_{\mathrm{obs}}$ were obtained from the slope of plot of $\ln$ (absorbance) versus time. A plot of $k_{\text {obs }}$ values versus $\mathrm{BCN}$ concentration allowed for the calculation of a second-order rate constant.

\subsection{Compound Stability Studies}

\subsubsection{Diene Stability in FBS}

A solution of MFP $(0.1 \mathrm{mM})$ or DFP $(0.1 \mathrm{mM})$ was prepared in phosphate-buffered saline containing fetal bovine serum $(10 \% v / v)$ and dimethyl sulfoxide (DMSO) $(2 \% v / v)$. Absorbance was measured at $335 \mathrm{~nm}$ (MFP) or $355 \mathrm{~nm}$ (DFP) with the baseline corrected to the solution without a diene. The solution was then incubated at $37^{\circ} \mathrm{C}$ for $8 \mathrm{~h}$, after which another absorbance reading was taken to determine the amount of remaining diene. Values are the mean $\pm \mathrm{SD}$ from triplicate assays.

\subsubsection{Diene Stability to Glutathione}

A solution of MFP $(0.1 \mathrm{mM})$ or DFP $(0.1 \mathrm{mM})$ was prepared in phosphate-buffered saline containing reduced glutathione $(1.0 \mathrm{mM})$, oxidized glutathione $(0.2 \mathrm{mM})$, and DMSO $(2 \% v / v)$. Absorbance was measured at $335 \mathrm{~nm}$ (MFP) or $355 \mathrm{~nm}$ (DFP) with the baseline corrected to the solution without a diene. The solution was then incubated at $37^{\circ} \mathrm{C}$ for $8 \mathrm{~h}$, after which another absorbance reading was taken to determine the amount of remaining diene. The assay was performed in triplicate.

\subsection{Computational Methods}

All calculations were performed at the M06-2X/6-311++G(d,p)//M06-2X/6-31G(d) level of theory using Gaussian 16, revision A.03 [29]. Optimized coordinates are listed in the Supplementary Materials.

\section{Conclusions}

We have developed an advantageous synthetic route to fluorinated $4 H$-pyrazoles that employs fluorination of the corresponding $1 H$-pyrazole. This late-stage fluorination strategy could be of utility beyond organic chemistry, given the utility of installing a fluoro group in nucleic acids [30], proteins [31,32], and drugs [33-36]. In addition, we showed that MFP has potential as a useful click reagent. Replacement of the fluoro group in DFP with a methyl group resulted in only a modest reduction in Diels-Alder reactivity that is accompanied by an increase in physiological stability.

Supplementary Materials: Supplementary materials can be found at http://www.mdpi.com/1422-0067/21/11/ 3964/s1 and include M06-2X/6-31G(d) optimized coordinates and ${ }^{1} \mathrm{H},{ }^{13} \mathrm{C}$, and ${ }^{19} \mathrm{~F}$ NMR spectra.

Author Contributions: Conceptualization, N.S.A. and B.J.L.; methodology, N.S.A. and B.J.L.; investigation, N.S.A. and B.J.L.; writing—original draft preparation, N.S.A.; writing—review and editing, B.J.L and R.T.R.; supervision, R.T.R.; funding acquisition, N.S.A., B.J.L. and R.T.R. All authors have read and agreed to the published version of the manuscript.

Funding: N.S.A. was supported by a Graduate Research Fellowship from the NSF. B.J.L. was supported by postdoctoral fellowship F32 GM137543 (NIH). This work was supported by Grant R01 GM044783 (NIH). Computational resources were provided by the Extreme Science and Engineering Discovery Environment (XSEDE) Bridges at the Pittsburgh Supercomputing Center through allocation TG-CHE190066. XSEDE is supported by Grant ACI-1548562 (NSF) [37].

Conflicts of Interest: The authors declare no conflict of interest. 


\section{References}

1. Diels, O.; Alder, K. Synthesen in der hydroaromatischen Reihe. Justus Liebigs Ann. Chem. 1928, 460, 98-122. [CrossRef]

2. Oliveira, B.L.; Guo, Z.; Bernardes, G.J.L. Inverse electron demand Diels-Alder reactions in chemical biology. Chem. Soc. Rev. 2017, 46, 4895-4950. [CrossRef] [PubMed]

3. Settle, A.E.; Berstis, L.; Rorrer, N.A.; Roman-Leshkov, Y.; Beckham, G.T.; Richards, R.M.; Vardon, D.R. Heterogeneous Diels-Alder catalysis for biomass-derived aromatic compounds. Green Chem. 2017, 19, 3468-3492. [CrossRef]

4. Stocking, E.M.; Williams, R.M. Chemistry and biology of biosynthetic Diels-Alder reactions. Angew. Chem. Int. Ed. 2003, 42, 3078-3115. [CrossRef] [PubMed]

5. Wu, H.; Devaraj, N.K. Inverse electron-demand Diels-Alder bioorthogonal reactions. Top. Curr. Chem. 2016, 374, 3. [CrossRef]

6. Nicolaou, K.C.; Snyder, S.A.; Montagnon, T.; Vassilikogiannakis, G. The Diels-Alder reaction in total synthesis. Angew. Chem. Int. Ed. 2002, 41, 1668-1698. [CrossRef]

7. Adam, W.; Ammon, H.; Nau, W.M.; Peters, K. 4-Halo-4H-pyrazoles: Cycloaddition with cyclopentadiene to azoalkanes of the 2,3-diazabicyclo[2.2.1] hept-2-ene type versus electrophilic addition with cyclopentene. J. Org. Chem. 1994, 59, 7067-7071. [CrossRef]

8. Adam, W.; Harrer, H.M.; Nau, W.M.; Peters, K. Electronic substituent effects on the acid-catalyzed [4 + 2] cycloaddition of isopyrazoles with cyclopentadiene and the photochemical and thermal denitrogenation of the resulting 1,4-diaryl-7,7-dimethyl-2,3-diazabicyclo[2.2.1] hept-2-ene azoalkanes to bicyclo[2.1.0]pentanes. J. Org. Chem. 1994, 59, 3786-3797. [CrossRef]

9. Beck, K.; Höhn, A.; Hünig, S.; Prokschy, F. Azobrücken aus Azinen, I. Isopyrazole als elektronenarme Diene zur Synthese von 2,3-Diazabicyclo[2.2.1] heptenen. Chem. Ber. 1984, 117, 517-533. [CrossRef]

10. Beck, K.; Hünig, S.; Klärner, F.-G.; Kraft, P.; Artschwager-Perl, U. Azobrücken aus Azinen, VII1) Diels-Alder-Reaktionen mit inversem Elektronenbedarf zwischen Isopyrazolen und Cycloalkenen sowie Cycloalkadienen-Ein Vergleich von Säure-Katalyse und Beschleunigung durch Druck. Chem. Ber. 1987, 120, 2041-2051. [CrossRef]

11. Levandowski, B.J.; Abularrage, N.S.; Houk, K.N.; Raines, R.T. Hyperconjugative antiaromaticity activates 4H-pyrazoles as inverse-electron-demand Diels-Alder dienes. Org. Lett. 2019, 21, 8492-8495. [CrossRef] [PubMed]

12. Fernández, I.; Wu, J.I.; Schleyer, P.V.R. Substituent effects on "hyperconjugative" aromaticity and antiaromaticity in planar cyclopolyenes. Org. Lett. 2013, 15, 2990-2993. [CrossRef] [PubMed]

13. Nyulászi, L.; Schleyer, P.V.R. Hyperconjugative $\pi$-aromaticity: How to make cyclopentadiene aromatic. J. Am. Chem. Soc. 1999, 121, 6872-6875. [CrossRef]

14. Levandowski, B.J.; Zou, L.; Houk, K.N. Schleyer hyperconjugative aromaticity and Diels-Alder reactivity of 5-substituted cyclopentadienes. J. Comput. Chem. 2016, 37, 117-123. [CrossRef]

15. Levandowski, B.J.; Zou, L.; Houk, K.N. Hyperconjugative aromaticity and antiaromaticity control the reactivities and $\pi$-facial stereoselectivities of 5-substituted cyclopentadiene Diels-Alder cycloadditions. J. Org. Chem. 2018, 83, 14658-14666. [CrossRef] [PubMed]

16. Kolb, H.C.; Finn, M.G.; Sharpless, K.B. Click chemistry: Diverse chemical function from a few good reactions. Angew. Chem. Int. Ed. 2001, 40, 2004-2021. [CrossRef]

17. Sammes, M.P.; Katritzky, A.R. The $4 H$-pyrazoles. In Advances in Heterocyclic Chemistry; Katritzky, A.R., Ed.; Academic Press: Cambridge, MA, USA, 1983; Volume 34, pp. 53-78.

18. Zelenin, K.N.; Tugusheva, A.R.; Yakimovich, S.I.; Alekseev, V.V.; Zerova, E.V. 5-Hydroxy-2-pyrazolines and some of their 1-substituted analogs. Chem. Heterocycl. Compd. 2002, 38, 668-676. [CrossRef]

19. Breen, J.R.; Sandford, G.; Patel, B.; Fray, J. Synthesis of 4,4-difluoro-1H-pyrazole derivatives. Synlett 2015, 26, 51-54. [CrossRef]

20. Walton, L.; Duplain, H.R.; Knapp, A.L.; Eidell, C.K.; Bacsa, J.; Stephens, C.E. Synthesis and charge density determination of 4,4-difluoro-3,5-diphenyl-4H-pyrazole and a hydrate derivative. J. Fluor. Chem. 2015, 173, 12-17. [CrossRef]

21. Yang, K.; Song, M.; Ali, A.I.M.; Mudassir, S.M.; Ge, H. Recent advances in the application of Selectfluor as a "fluorine-free" functional reagent in organic synthesis. Chem.-Asian J. 2020, 15, 729-741. [CrossRef] 
22. Nyffeler, P.T.; Durón, S.G.; Burkhart, M.D.; Vincent, S.P.; Wong, C.-H. Selectfluor: Mechanistic insight and applications. Angew. Chem. Int. Ed. 2004, 44, 192-212. [CrossRef] [PubMed]

23. Rozatian, N.; Ashworth, I.W.; Sandford, G.; Hodgson, D.R.W. A quantitative reactivity scale for electrophilic fluorinating reagents. Chem. Sci. 2018, 9, 8692-8702. [CrossRef] [PubMed]

24. Zhao, Y.; Truhlar, D.G. The M06 suite of density functionals for main group thermochemistry, thermochemical kinetics, noncovalent interactions, excited states, and transition elements: Two new functionals and systematic testing of four M06-class functionals and 12 other functionals. Theor. Chem. Acc. 2008, 120, 215-241. [CrossRef]

25. Stanger, A. Can substituted cyclopentadiene become aromatic or antiaromatic? Chem. Eur. J. 2006, 12, 2745-2751. [CrossRef]

26. Levandowski, B.J.; Houk, K.N. Hyperconjugative, secondary orbital, electrostatic, and steric effects on the reactivities and endo and exo stereoselectivities of cyclopropene Diels-Alder reactions. J. Am. Chem. Soc. 2016, 138, 16731-16736. [CrossRef]

27. Sloop, J.C.; Jackson, J.L.; Schmidt, R.D. Microwave-mediated pyrazole fluorinations using Selectfluor ${ }^{\circledR}$. Heteroat. Chem. 2009, 20, 341-345. [CrossRef]

28. Lyles, M.M.; Gilbert, H.F. Catalysis of the oxidative folding of ribonuclease A by protein disulfide isomerase: Dependence of the rate on the composition of the redox buffer. Biochemistry 1991, 30, 613-619. [CrossRef]

29. Frisch, M.J.; Trucks, G.W.; Schlegel, H.B.; Scuseria, G.E.; Robb, M.A.; Cheeseman, J.R.; Scalmani, G.; Barone, V.; Petersson, G.A.; Nakatsuji, H.; et al. Gaussian 16, Revision A.03; Gaussian, Inc.: Wallingford, CT, USA, 2016.

30. Guo, F.; Li, Q.; Zhou, C. Synthesis and biological applications of fluoro-modified nucleic acids. Org. Biomol. Chem. 2017, 22, 9552-9565. [CrossRef]

31. Buer, B.C.; Marsh, E.N. Fluorine: A new element in protein design. Protein Sci. 2012, 21, 453-462. [CrossRef]

32. Odar, C.; Winkler, M.; Wiltschi, B. Fluoro amino acids: A rarity in nature, yet a prospect for protein engineering. Biotechnol. J. 2015, 10, 427-446. [CrossRef]

33. Purser, S.; Moore, P.R.; Swallow, S.; Gouverneur, V. Fluorine in medicinal chemistry. Chem. Soc. Rev. 2008, 37, 320-330. [CrossRef] [PubMed]

34. Müller, K.; Faeh, C.; Diederich, F. Fluorine in pharmaceuticals: Looking beyond intuition. Science 2007, 317, 1881-1886. [CrossRef] [PubMed]

35. Hagmann, W.K. The many roles for fluorine in medicinal chemistry. J. Med. Chem. 2008, 51, 4359-4369. [CrossRef] [PubMed]

36. Mei, H.; Han, J.; Klika, K.D.; Izawa, K.; Sato, T.; Meanwell, N.A.; Soloshonok, V.A. Applications of fluorine-containing amino acids for drug design. Eur. J. Med. Chem. 2020, 186, 111826. [CrossRef] [PubMed]

37. Towns, J.; Cockerill, T.; Dahan, M.; Foster, I.; Gaither, K.; Grimshaw, A.; Hazlewood, V.; Lathrop, S.; Lifka, D.; Peterson, G.D.; et al. XSEDE: Accelerating scientific discovery. Comput. Sci. Eng. 2014, 16, 62-74. [CrossRef] 